\title{
A Study on the College Students' Autonomous Learning Competence
}

\author{
Lang Yongqing \\ Dept. of Humanities and Social Sciences, Beijing Electronic Science and Technology Institute, Beijing, China \\ lance@besti.edu.cn
}

\begin{abstract}
Recently learner autonomy has received much attention in the field of language teaching and learning. After reviewing much literature, this study surveyed 42 non-English majors in Beijing Electronic Science and Technology Institute on their English language autonomous learning competence. The findings showed the participants were generally low in learner autonomy competence. Reasons were also discussed in this paper. Students' motivation, attitude towards learner autonomy and lack of metacognitive knowledge account for this phenomenon. Teachers and students should take positive attitude towards learner autonomy and both of them must take on and adjust to the new roles in teaching and learning. Metacognition is important for language learner. Also ICT use in language learning (e-learning) is an option to promote learner autonomy.

Index terms - learner autonomy, cognition, metacognition.
\end{abstract}

\section{Introduction}

The field of foreign language learning and teaching has been in a constant state of change over the last twenty years. The main one has been a shift of focus from the teacher onto the language learner. That is, the emphasis of research has shifted from "how to teach" to "how to learn" in the field of foreign language teaching and learning. Corresponding to this shift, an interest, since the early 1970 s, in the learner and the learner's learning has been growing in the field of second language acquisition. Consequently, this interest has been reflected in the notion of learner autonomy (LA), which has been described and defined in a number of ways with regard to language learning and teaching. The most frequently quoted definition of LA is that of Holec (1981:3), who defined autonomy as "the ability to take charge of one's own learning".

In China, there are always problems in English learning and teaching. Since China adopted opening policy and economic reform, English is a required course in Chinese primary schools, middle schools and universities. However, it is true that after studying English for over ten years, most university students continue to find learning English a difficult task. Many students who are able to pass the English examinations with high grades are frequently poor at using the language. One of the reasons is the traditional teacher-centered model had a long-lasting influence on TEFL (Teaching English as a Foreign Language) practice in China. Chinese learners are characterized as dependent, lacking in intellectual initiative and inclining to favor rote learning over creative learning (Biggs, 1991, 1992). Without teachers' direction and assignment they do not know what to learn and how to learn after class. The tradition of teacher-centered and didactic learning modes does not seem a promising ground for the promotion of learner autonomy (Chan, 2003). Shi Zhenmei (2005) commented the existing level of self-regulation in Chinese students was clearly revealed by the frequency of teacher's complaints about students' daydreaming in classrooms, poor assignments and seldom completion of homework and so on. Little room is made for freedom of expression, independence, self-mastery and creativity (Murphy, 1987).

Recently the concept of learner autonomy has received much attention from Chinese English teachers and it has been regarded as an effective method in language learning and teaching. However, compared with the western countries, related research in this area is relatively few. The relevant studies to date in China either stay on pure theoretical framework, or belong to empirical research. Descriptions and evaluations of students' current autonomous problems and possible suggestions on how to improve their autonomous competence are scarce.

This study is to investigate students' autonomous English learning situation and discovering their autonomous problems so as to find out possible ways to promote their autonomy correspondingly.

\section{Literature review}

\section{A . Definitions of learner autonomy}

Learner autonomy has had a history of approximately three decades. Nowadays, autonomy has been widely accepted as an educational goal and "few teachers will disagree with the importance of helping language learners become more autonomous as learners" (Wenden, 1991:11). But as to what learner autonomy really is, linguists and educationalists have failed to reach a consensus.

Holec (1981:3) defines learner autonomy as "the ability to take charge of one's own learning". This ability has "a potential capacity to act in a given situation and not the actual behavior of an individual in that situation". So for Holec, learner autonomy is ability, not an action.

For Huttunen (1986:95) the act of a certain type of learning is important. In his view, "a learner is fully autonomous when he is working individually or in a group, taking responsibility for the planning, monitoring and evaluation of his studies..." Unlike Holec, who defines autonomy in terms of ability, Huttunen defines it in terms of performance. 


\section{B . Researches on learner autonomy}

As mentioned above, there has been a shift of focus from the teacher onto the language learner. The reasons for this shift are twofold: both goals of language learning and insights into the process of language learning have changed. Society has posed its demands on education and has had great influence. Research in fields such as pedagogical theory, cognitive psychology, sociology, linguistics and others; have added to our knowledge of how language learning takes place. These two developments have, among others, led to a greater interest in Learner Autonomy.

\section{1) Social development and its demands:}

After World War Two the demand for foreign and second languages sharply increased (Gremmo and Riley 1995). International trade, easier communication, cheaper transportation, international political developments and the migrant movements all led to an increase in the teaching of foreign and second languages. Recently changes in society have led to the need for life-long learning. Education must provide the skills necessary for this process.

With the development of the Internet, great changes have taken place in foreign language teaching. Many scholars show their concern on the autonomous learning in network teaching. The advances of communication and information technologies(ICT) have also contributed to providing resources for autonomous learning (e.g., giving access to a wider range of language resources on the Internet; giving a larger audience access to language learning through open and distance education) (Maud, 2007). .

\section{2) Pedagogical theory}

One of the pedagogical justifications for the raising of autonomy in learning foreign languages is the need to help learners to learn how to learn so as to meet the needs for continuing or life education. Nowadays, many teachers and educationalists see learning how to learn as the most basic and important educational objective, no matter what teaching or learning mode is adopted. Rogers(1969:135) stated the need boldly, "The only man who is educated is the man who has learned how to learn; the man who has learned how to adapt and change; the man who has realized that no knowledge is secure, that only the process of seeking knowledge gives a basis for security". Brown (2002:87) believes that in adopting Rogers's ideas to language teaching and learning we need to see to it that learners understand themselves and communicate this self to others freely and non-defensively. Teachers as facilities must therefore provide the nurturing context for learning and not see their mission as one of rather programmatically feeding students quantities of knowledge which they subsequently devour. Boud (1988:18) pointed out "a fundamental purpose of education is assumed to be to develop in individuals the ability to make their own decisions about what they think and do"

\section{3) Cognitive psychology}

Many developments in cognitive psychology have had a strong influence on ideas about language teaching and learning.
The development of learner autonomy gains supports from the notion that knowing and thinking develops with experiences. Philosophers such as Rousseau and Dewey put these ideas forward a long time ago. They emphasized that if learning is not perceived by a learner to be meaningful, it is less likely to be incorporated into internal schemes, that is: it might be learned and remembered, but not become part of a learner's internal representation of the world. Learners have to work actively with these internal schemes. They need to compare new information with existing knowledge, look for similarities, organize new knowledge logically etc. Ultimately, this is perhaps where real autonomy lies.

\section{4) Metacognition}

Metacognition is our knowledge of cognitive processes. According to Hacker, Dunlosky and Graesser(1998), metacognitive awareness consists of three parts: thinking of what one knows (metacognitive knowledge), thinking of what one is currently doing (metacognitive skill) and thinking of what one's current cognitive or affective state is (metacognitive experience). All this knowledge, the beliefs and perceptions are related to learner autonomy, because they are needed to make informed decisions about one's learning. If it is the aim of education to let learners take charge of their own learning, then they need to be able to plan, monitor and evaluate their learning.

\section{Characteristics of learner autonomy}

According to Leslie Dickinson, autonomy is seen as an attitude toward language learning, which may not necessarily have many external, observable features. But in terms of that attitude, he thinks of autonomous learners as people who are characterized in a number of ways. He has listed five points (Dickinson 1993). Firstly, they are able to identify what's been taught. More importantly, they see the importance of doing that, of being concerned about what they are trying to do. So, they are aware of the teacher's objectives. Secondly, they are able to formulate their own learning objectives, not necessarily in competition with the teacher. But more often in collaboration with the teacher, or as something which is in addition to what the teacher is doing. Thirdly, they can and do select and implement appropriate learning strategies, often consciously. Fourthly, they are able to identify strategies that are not working for them, that are not appropriate, and use others. Finally, they can assess their own achievement. In other words, they can monitor their own learning.

\section{Methodology}

This study is designed to investigate non-English majors' autonomous English learning situation and to evaluate their autonomous English learning competence through a questionnaire. It aims to measure the degree of students' autonomous English learning competence from the following five perspectives (put forward by Dickinson 1993 and mentioned above):

1) Identifying what has been taught in class;

2) Formulating the learning objectives; 
3) Selecting and implementing appropriate learning strategies;

4) Monitoring the use of learning strategies;

5) Monitoring and evaluating the learning.

The main objective of the study is to identify students' weak points in autonomous learning and explore some possible strategies to cultivate and promote learner autonomy in the current Chinese context.

\section{A . Participants}

42 freshmen (non-English majors) from one class of Beijing Electronic Science and Technology Institute participated in this study. These students major in computer science. Of the 42 samples, 30 were males, 12 were females. Each week they have four English classes, and fifty minutes for each class. All the participants had at least studied English as a foreign language for over seven years, and they had different personalities and different proficiency levels in English as well. In the placement English test as the freshmen, 8 students achieved above 85; 5 students failed; 29 students scored between 60 and 84 ..

\section{B. Questionnaire}

The questionnaire employed in this study is an adaptation of 2 questionnaires, which are Wen's The Learner Strategy Questionnaire (1995) and Broady's Learner Attitudes towards Self-direction Questionnaire (1996).

To measure the degree of students' autonomous English learning competence on a five-point Likert Scale $(\mathrm{SD}=$ strongly disagree, $\mathrm{D}=$ disagree, $\mathrm{U}=$ neutral, $\mathrm{A}=$ agree, $\mathrm{SA}=$ strongly agree), the questionnaire consists of 30 statements and mainly covers five aspects: identifying what has been taught; formulating the learning objectives; selecting and implementing appropriate learning strategies; monitoring the use of learning strategies; monitoring and evaluating the learning. These items are randomly arranged in the questionnaire, for categorized arrangement may have some influence on students' responses to the questions. A Chinese version of the questionnaire is adopted so that it is easier for the students to understand the meaning accurately and quickly.

The questionnaire was administered in the students' English class. The participants were assured that their names would be kept anonymous in order to express their true ideas and attitudes about language learning.

\section{Data analysis}

The quantitative data were calculated manually. The descriptive statistical analyses were applied to calculate the percentages concerned in the questionnaire. The results obtained from the quantitative analysis were listed in the tables, and were used to measure the level of students' autonomy.

\section{Results}

This table illustrates the percentages of identifying what has been taught in class. The high SD, D and U percentage in the items 3,7,10 and 18 indicated that a lot of students did not know what was going on in their class. More than $40 \%$ students could not clearly identify the teachers' teaching aim, and $45.2 \%$ of the students were not sure of it (item 3). About $43 \%$ of the students could not successfully make the teachers' aim and purposes their own (item18). Plus the neutral answers, we can conclude from this table that most of the students were not fully aware of the teaching objectives, although more than $61 \%$ of the students (item 24) could keep up with the teachers' teaching pace.

TABLE 1 Results on identifying what has been taught.

\begin{tabular}{|c|c|c|c|c|c|c|}
\hline \multirow{2}{*}{ Items } & \multirow{2}{*}{ Content } & \multicolumn{5}{|c|}{ Percentage } \\
\hline & & SD & $\mathrm{D}$ & $\mathrm{U}$ & A & SA \\
\hline 3 & $\begin{array}{l}\text { Clearly identifying the teachers' } \\
\text { teaching aims. }\end{array}$ & 4.8 & 35.7 & 45.2 & 9.5 & 4.8 \\
\hline 7 & $\begin{array}{c}\text { Clearly identifying the purpose of } \\
\text { class activities set by the teachers in } \\
\text { class. }\end{array}$ & 2.4 & 23.8 & 45.2 & 21.4 & 7.1 \\
\hline 10 & $\begin{array}{c}\text { Knowing the importance of making } \\
\text { the teachers' aims and purposes their } \\
\text { own. }\end{array}$ & 4.8 & 26.2 & 40.5 & 19 & 9.5 \\
\hline 18 & $\begin{array}{l}\text { Successfully making the teachers' } \\
\text { aims and purposes their own. }\end{array}$ & 4.8 & 38.1 & 23.8 & 23.8 & 9.5 \\
\hline 24 & $\begin{array}{l}\text { Keeping up with the teachers' } \\
\text { teaching pace. }\end{array}$ & 2.4 & 14.3 & 21.4 & 50 & 11.9 \\
\hline
\end{tabular}

This table indicated that the majority of students $(4.8 \%+33.3 \%+38.1 \%$ in item 1$)$ did not have clear schedule of English learning besides assignments of the teacher. And they were not able to set practical learning goals (item 6: $2.4 \%+35.8 \%+35.8 \%$ ). Also a large number of students (at least $60 \%$ ) can not plan the study time well (item 19). Although more than $30 \%$ of the students have a clear goals for improving English (item11), we can clearly conclude from this table that quite a big number of students were incapable of formulating their own learning objectives.

TABLE 2 results on formulating the learning objectives

\begin{tabular}{|c|c|c|c|c|c|c|}
\hline \multirow{2}{*}{ Items } & \multirow{2}{*}{ Content } & \multicolumn{5}{|c|}{ Percentage } \\
\hline & & SD & $\mathrm{D}$ & $\mathrm{U}$ & A & SA \\
\hline 1 & $\begin{array}{c}\text { Having clear schedule of English } \\
\text { learning besides assignments of the } \\
\text { teacher. }\end{array}$ & 4.8 & 33.3 & 38.1 & 16.7 & 7.1 \\
\hline 6 & Setting practical learning goals & 2.4 & 35.8 & 35.8 & 19 & 7.1 \\
\hline 11 & $\begin{array}{l}\text { Having clear goals for improving } \\
\text { English }\end{array}$ & 0 & 19 & 40 & 28.6 & 11.9 \\
\hline 19 & Planning the study time well & 2.4 & 23.8 & 45.2 & 21.4 & 7.1 \\
\hline 25 & $\begin{array}{c}\text { Clearly identifying the demands for } \\
\text { listening, speaking, reading, } \\
\text { writing, and translating of CET-4 }\end{array}$ & 4.8 & 26.2 & 42.9 & 21.4 & 4.8 \\
\hline
\end{tabular}

This table indicated that most of the students $(11.9 \%+45.2 \%+$ neutral $31 \%$ in item 2$)$ did not have a relatively rich repertoire of strategy selection and implementation. Also a high percentage of students could not implement communication strategies in conversations (item 23) 
TABLE 3 results on selecting and implementing appropriate learning strategies

\begin{tabular}{|c|c|c|c|c|c|c|}
\hline \multirow{2}{*}{ Items } & Content & \multicolumn{5}{c|}{ Percentage } \\
\cline { 5 - 8 } & & $\mathrm{SD}$ & $\mathrm{D}$ & $\mathrm{U}$ & $\mathrm{A}$ & $\mathrm{SA}$ \\
\hline 2 & $\begin{array}{c}\text { Having a relatively rich repertoire of } \\
\text { strategy selection and implementation }\end{array}$ & 11.9 & 45.2 & 31 & 9.5 & 2.4 \\
\hline \multirow{2}{*}{23} & $\begin{array}{c}\text { Implementing appropriate listening } \\
\text { strategies consciously in listening } \\
\text { exercise. }\end{array}$ & 2.4 & 14.3 & 50 & 26.2 & 7.1 \\
\hline \multirow{2}{*}{28} & $\begin{array}{c}\text { Implementing appropriate } \\
\text { communication strategies consciously in } \\
\text { a conversation. }\end{array}$ & 7.1 & 38.1 & 40 & 9.5 & 4.8 \\
\hline \multirow{2}{*}{30} & $\begin{array}{c}\text { Implementing appropriate reading } \\
\text { strategies consciously in reading } \\
\text { exercises. }\end{array}$ & 2.4 & 9.5 & 28.6 & 50 & 9.5 \\
\hline \multirow{2}{*}{$\begin{array}{c}\text { Implementing appropriate writing } \\
\text { strategies consciously in writing } \\
\text { exercises. }\end{array}$} & 4.8 & 19 & 47.6 & 26.2 & 2.4 \\
\hline
\end{tabular}

From item 22 and 29 we can easily find more than half and more than $42 \%$ of the students, respectively, often evaluate the learning strategies and were able to use other more strategies after they had identified the strategies were not appropriate for them. However, a large number of students could not monitor the use strategies well (item 4, 12, 14 and $16)$.

TABLE 4 results on monitoring the use of learning strategies

\begin{tabular}{|c|c|c|c|c|c|c|}
\hline \multirow{2}{*}{ Items } & Content & \multicolumn{5}{|c|}{ Percentage } \\
\cline { 3 - 7 } & & SD & D & U & A & SA \\
\hline 4 & $\begin{array}{c}\text { Monitoring the use of } \\
\text { communication strategies } \\
\text { consciously in a conversation. }\end{array}$ & 7.1 & 33.3 & 47.6 & 9.5 & 2.4 \\
\hline 12 & $\begin{array}{c}\text { Monitoring the use of writing } \\
\text { strategies consciously in writing } \\
\text { exercises. }\end{array}$ & 9.5 & 42.9 & 33.3 & 14.3 & 0 \\
\hline 14 & $\begin{array}{c}\text { Monitoring the use of reading } \\
\text { strategies consciously in reading } \\
\text { exercises }\end{array}$ & 2.4 & 21.4 & 35.8 & 31 & 9.5 \\
\hline 16 & $\begin{array}{c}\text { Monitoring the use of listening } \\
\text { strategies consciously in listening } \\
\text { exercises }\end{array}$ & 4.8 & 19 & 42.9 & 26.2 & 7.1 \\
\hline 22 & $\begin{array}{c}\text { Often evaluating the learning } \\
\text { strategies to find out the ineffective } \\
\text { ones and improve them. }\end{array}$ & 2.4 & 19 & 23.8 & 45.2 & 9.5 \\
\hline 29 & $\begin{array}{c}\text { Being able to use other more } \\
\text { appropriate strategies after you had } \\
\text { identified the strategies were not } \\
\text { appropriate for you. }\end{array}$ & 2.4 & 14.3 & 40 & 40 & 2.4 \\
\hline
\end{tabular}

In item 5 of this table, the majority of the students (about $43 \%$ disagreement plus 50\% neutral) were not actively looking for opportunities to practice English in class or out of class. Also high percentage of disagreement and neutral answers were found in item 13, 17, 26 and 27, which indicate a lot of students could not consciously apply new knowledge to practice, not active in collaboration with others, did not often check how well a plan was working in learning tasks and didn't often check and correct the comprehension in the course of a language task.
TABLE 5 results on monitoring and evaluating the learning

\begin{tabular}{|c|c|c|c|c|c|c|}
\hline \multirow{2}{*}{ Items } & \multirow{2}{*}{ Content } & \multicolumn{5}{|c|}{ Percentage } \\
\hline & & $\mathrm{SD}$ & $\mathrm{D}$ & $\mathrm{U}$ & $\mathrm{A}$ & SA \\
\hline 5 & $\begin{array}{l}\text { Actively looking for opportunities to } \\
\text { practice English in class or out of } \\
\text { class. }\end{array}$ & 11.9 & 31 & 50 & 4.8 & 2.4 \\
\hline 8 & $\begin{array}{c}\text { Often actively overcoming the } \\
\text { affective factors that are not good for } \\
\text { English learning. }\end{array}$ & 7.1 & 16.7 & 33.3 & 38.1 & 4.8 \\
\hline 9 & $\begin{array}{l}\text { Often making use of the available } \\
\text { learning sources. }\end{array}$ & 4.8 & 4.8 & 38.1 & 35.8 & 16.7 \\
\hline 13 & $\begin{array}{c}\text { Consciously applying the newly got } \\
\text { knowledge into practice. }\end{array}$ & 4.8 & 38.1 & 38.1 & 14.3 & 4.8 \\
\hline 17 & $\begin{array}{c}\text { Being active in collaboration with } \\
\text { others in language learning }\end{array}$ & 9.5 & 47.6 & 35.8 & 7.1 & 0 \\
\hline 20 & $\begin{array}{c}\text { Being able to find out the reasons for } \\
\text { language errors and take measure to } \\
\text { correct errors. }\end{array}$ & 2.4 & 14.3 & 35.8 & 40 & 7.1 \\
\hline 21 & $\begin{array}{c}\text { Being able to find out all about how to } \\
\text { be a better language learner. }\end{array}$ & 4.2 & 16.7 & 47.6 & 26.2 & 7.1 \\
\hline 26 & $\begin{array}{c}\text { Often checking how well a plan is } \\
\text { working in the course of a language } \\
\text { task }\end{array}$ & 7.1 & 42.9 & 35.8 & 9.5 & 4.8 \\
\hline 27 & $\begin{array}{l}\text { Often checking and correcting the } \\
\text { comprehension in the course of a } \\
\text { language task. }\end{array}$ & 4.8 & 40 & 33.3 & 14.3 & 7.1 \\
\hline
\end{tabular}

\section{E.Discussion}

The results from the quantitative data indicate the students in the survey are at the low level of autonomous learning competence.

Motivation is one of the key factors that influence the rate and success of foreign language learning. When motivation has been discussed in relation to autonomy in language learning, it has often been put forward as a product of autonomy. Spratt's (2002) study suggested a more complex relationship in which motivation in many cases precedes autonomy. Motivation is a key factor that influences the extent to which learners are ready to learn autonomously, and that teachers might therefore Endeavour to ensure motivation before they train students to become autonomous (Spratt, et al, 2002). In China, most students admitted that exams were what motivated them to study hard in language learning, which indicated that most of students were learning mainly for the purpose of passing exams. If students are only extrinsically motivated by exams and marked exercises, then they are less likely to develop the motivation needed to sustain greater autonomy (Dickinson, 1987).

As indicated by the research results, it could be seen that the students were not fully aware of the teachers' teaching objectives; they were not competent in checking how well a plan was working in the course of a language task, in applying the newly got knowledge into practice and in implementing and monitoring the learning strategies, etc. All these disclose the fact that the students lack the metacognitive knowledge and strategies required for autonomous language learning.

\section{F. Implication}

Having positive attitudes for autonomy is a prerequisite for both teachers and students to be involved in autonomous 
learning mode. So it is no wonder that directing their attitudes towards autonomy has become our first concern. Teachers will take the new roles as facilitator, counselor and resource. Students should take a positive attitude toward learn autonomy and be actively involved in learning activities.

Metacognitive awareness needs to be enhanced. According to Wenden (1991:34), learners use metacognitive strategies to oversee and manage their learning. In a sense, metacognitive strategies are skills used for planning, monitoring, and evaluating the learning activity; "they are strategies about learning rather than learning strategies themselves" (Cook, 1993:114).

E-Learning could be an option for promoting learner autonomy. Once students are well motivated, it will be a great step forward for their English learning. Compared with traditional learning, e-learning could be more effective to arouse students' interest. With the popularity of computers on campus, e-learning may become a positive aid of the English learning and teaching programs. Just as mentioned previously in this article, the advances of ICT have also contributed to providing resources for autonomous language learning (e.g., giving access to a wider range of language resources on the Internet; giving a larger audience access to language learning through open and distance education) (Maud 2007).

\section{Conclusion}

This investigation looked into the autonomous English learning competence of non-English majors in China through a questionnaire. The findings from the quantitative data indicate that the non-English majors surveyed were poor at learner autonomy competence in their English language learning. Several factors contributed to the reasons of this phenomenon such as the student's attitudes and motivation, lack of metacognitive knowledge and learning strategies. Some ways to foster the learner autonomy were recommended. Teachers and students should have positive attitude towards learner autonomy and both of them must take on new roles. Metacognition must be enhanced. And finally ICT use in language learning (e-learning) is an option to promote learner autonomy.

\section{References}

[1] Biggs, J. B. (1992). Why and how do Hong Kong students learn? Using the Teaming and Study Process Questionnaires. Education Paper19 (pp.158-162). Hong Kong: Hong Kong University Press.

[2] Boud, D. (1988). Moving towards autonomy. In D. Boud (Ed.), Developing student autonomy in learning (pp. 17-39). London: Kogan.

[3] Broady, E.\&Kenning, M. M. (Eds.). 1996. Promoting learner autonomy in university language teaching. London: Association for French Language studies in association with CILT 215-235.

[4] Brown, H.D. 2002. Principles of Language Learning and Teaching. Beijing, Foreign Language Teaching and Research Press. p. 85-87.

[5] Chan, V. (2003). Autonomous language learning: The teachers' perspectives. Teaching in Higher Education, 8, 33-54

[6] Cook, V., 1993, Linguistics and Second Language Acquisition, Macmillan,.

[7] Dickinson, L. (1987). Self-instruction in language learning. Cambridge: Cambridge University Press.

[8] Dickinson, L. 1993. Talking Shop: Aspects of Autonomous Learning. ELT Journal 47:4, 330-35

[9] Hacker, D. J. Dunlosky and Graesser, A. (ed.). 1998. Metacognition in Educational

[10] Theory and Practice. Hillsdale, N. J.: Lawrence Erlbaum.

[11] Holec, H. (1981).Autonomy and foreign language learning. Oxford: Pergamon.

[12] Huttunen, L. 1986. Towards Learner Autonomy in Foreign Language Learning in Senior Secondary School. University of Oulou.

[13] Maud Ciekanski 2007 Fostering learner autonomy: power and reciprocity in the relationship between language learner and language learning adviser. Cambridge Journal of Education Vol. 37, No.1 111 127.

[14] Rogers, C. (1969). Freedom to learn: A view of what education might become. Columbus OH: Charles E. Merrill.

[15] Shi Zhenmei 2005. Applications of Research on SRL into English Classroom Practices. CELEA Journal Vol.28 No.5 92-93

[16] Spratt, Mary, Gillian Humphreys and Victoria Chan Autonomy and motivation: which comes first? Hong Kong Polytechnic University, Language Teaching Research 6,3 (2002); pp. 245-266

[17] Wenden, A. L. 1991. Strategies for Autonomy. London: PrenticeHall.

[18] Wen Qiufang, 1995, On English Learning Strategies 